\title{
A HARBINGER OF SPRING
}

\author{
Arch. C. Budd, Swift Current.
}

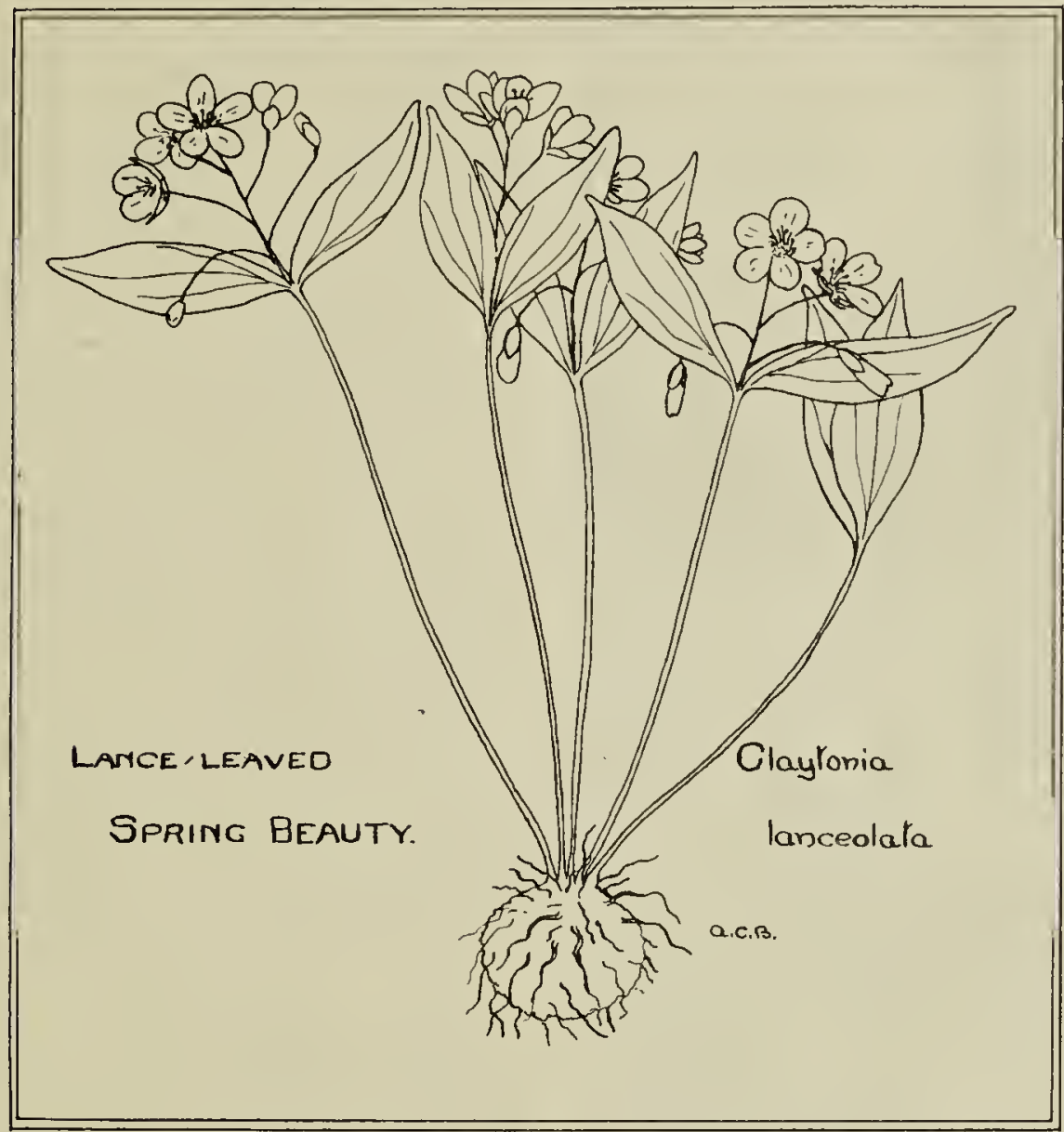

The Lanced-leaved Spring Beauty, Claytonia lanceolata, is a plant which deserves to be better known, as it is one of the earliest of our spring flowers. Unfortunately, in our Province, it is restricted to the Cypress Hills and blooms when that prairie oasis is a little difficult to reach. When the snow in the hills has almost disappeared the Spring Beauty can be found in great profusion along the margins of the woodlands and on the banks of ravines close to the remaining snowbanks. Often what appears at first sight to be a snow bank proves to be a mass of Claytonia, some flowers even protruding through the snow.

The plant belongs to the Portulaca family, has two stalkless, opposite leaves part way up the stem, and bears a loose raceme of white flowers, with an occasional pinkish tinge. The flowers, which are from $1 / 2$ to $3 / 4$ inch in diameter, have 2 sepals, 5 petals and 5 tiny yellow stamens, and are boren in a raceme of from 4 to 15 flowers. The root is a globose corm from $1 / 2$ to $3 / 4$ inch in diameter, and is generally from 3 to 5 inches below the surface, sometimes with only one, but often with 6 or 7 stems arising. These fleshy roots were dug by the
Indians and eaten either raw, boiled or roasted.

Spring Beauty is quite plentiful in the Foothills Region and in the lower levels of the Rocky Mountains from Canada to New Mexico. The scientific name is in honour of John Clayton, one of America's earliest botanists who died in 1773.

These plants seem to transplant well if taken with a good ball of soil, and are my earliest flowering garden plants, being in bloom on the north of the house on May 5 in 1951 and April 27 in 1952. In the Cypress Hills we have found them about mid-IMay as a rule.

\section{Maytime}

Come out, come out, the earth is green,

Behold the budding tree

And bluebirds where late snows have been,

The robin sings with glee,

They call to all enticingly

To come where soft winds blow

The miracle of life to see-

For May days quickly go.

Ethel Eroll Boyd. Calgary, Alberta. 